\title{
Re-evaluating black carbon in the Himalayas and the Tibetan Plateau: concentrations and deposition
}

\author{
Chaoliu Li ${ }^{1,3,4}$, Fangping Yan $^{3}$, Shichang Kang ${ }^{2,4}$, Pengfei Chen ${ }^{2}$, Xiaowen Han ${ }^{1,5}$, Zhaofu Hu ${ }^{2,5}$, Guoshuai Zhang ${ }^{1}$, \\ Ye Hong ${ }^{6}$, Shaopeng Gao ${ }^{1}$, Bin $\mathbf{Q u}^{3}$, Zhejing $\mathrm{Zhu}^{7}$, Jiwei $\mathbf{L i}^{7}$, Bing Chen ${ }^{7}$, and Mika Sillanpää̈ \\ ${ }^{1}$ Key Laboratory of Tibetan Environment Changes and Land Surface Processes, Institute of Tibetan Plateau Research, \\ Chinese Academy of Sciences, Beijing 100101, China \\ ${ }^{2}$ State Key Laboratory of Cryospheric Sciences, Northwest Institute of Eco-Environment and Resources, \\ Chinese Academy of Sciences, Lanzhou 730000, China \\ ${ }^{3}$ Laboratory of Green Chemistry, Lappeenranta University of Technology, Sammonkatu 12, 50130 Mikkeli, Finland \\ ${ }^{4}$ CAS Center for Excellence in Tibetan Plateau Earth Sciences, Beijing 100101, China \\ ${ }^{5}$ University of Chinese Academy of Sciences, Beijing 100049, China \\ ${ }^{6}$ Institute of Atmospheric Environment, China Meteorological Administration, Shenyang 110166, China \\ ${ }^{7}$ Environmental Research Institute, Shandong University, Jinan 250100, China \\ ${ }^{8}$ Department of Civil and Environmental Engineering, Florida International University, Miami, FL 33174, USA
}

Correspondence to: Chaoliu Li (lichaoliu@itpcas.ac.cn)

Received: 7 March 2017 - Discussion started: 3 April 2017

Revised: 29 August 2017 - Accepted: 1 September 2017 - Published: 9 October 2017

\begin{abstract}
Black carbon (BC) is the second most important warming component in the atmosphere after $\mathrm{CO}_{2}$. The $\mathrm{BC}$ in the Himalayas and the Tibetan Plateau (HTP) has influenced the Indian monsoon and accelerated the retreat of glaciers, resulting in serious consequences for billions of Asian residents. Although a number of related studies have been conducted in this region, the $\mathrm{BC}$ concentrations and deposition rates remain poorly constrained. Because of the presence of arid environments and the potential influence of carbonates in mineral dust (MD), the reported BC concentrations in the HTP are overestimated. In addition, large discrepancies have been reported among the $\mathrm{BC}$ deposition derived from lake cores, ice cores, snow pits and models. Therefore, the actual BC concentration and deposition values in this sensitive region must be determined. A comparison between the $\mathrm{BC}$ concentrations in acid $(\mathrm{HCl})$-treated and untreated total suspected particle samples from the HTP showed that the $\mathrm{BC}$ concentrations previously reported for the Nam Co station (central part of the HTP) and the Everest station (northern slope of the central Himalayas) were overestimated by approximately $52 \pm 35$ and $39 \pm 24 \%$, respectively, because of the influence of carbonates in MD. Additionally, the organic carbon (OC) levels were overestimated by approxi-
\end{abstract}

mately $22 \pm 10$ and $22 \pm 12 \%$ for the same reason. Based on previously reported values from the study region, we propose that the actual BC concentrations at the Nam Co and Everest stations are 61 and $154 \mathrm{ng} \mathrm{m}^{-3}$, respectively. Furthermore, a comprehensive comparison of the BC deposition rates obtained via different methods indicated that the deposition of BC in HTP lake cores was mainly related to river sediment transport from the lake basin as a result of climate change (e.g., increases in temperature and precipitation) and that relatively little $\mathrm{BC}$ deposition occurred via atmospheric deposition. Therefore, previously reported BC deposition rates from lake cores overestimated the atmospheric deposition of BC in the HTP. Correspondingly, BC deposition derived from snow pits and ice cores agreed well with that derived from models, implying that the BC depositions of these two methods reflect the actual values in the HTP. Therefore, based on reported values from snow pits and ice cores, we propose that the BC deposition in the HTP is $17.9 \pm 5.3 \mathrm{mg} \mathrm{m}^{-2} \mathrm{a}^{-1}$, with higher and lower values appearing along the fringes and central areas of the HTP, respectively. These adjusted BC concentrations and deposition values in the HTP are critical for performing accurate evalua- 
tions of other BC factors, such as atmospheric distribution, radiative forcing and chemical transport in the HTP.

\section{Introduction}

The Himalayas and the Tibetan Plateau (HTP) region is the highest mountain-plateau system in the world and is the source of approximately 10 large rivers in Asia. This region is also sensitive to climate change (Bolch et al., 2012; Kang et al., 2010; You et al., 2010). Black carbon (BC) in and around the HTP has been found to play key roles in climate change patterns in the HTP and Asia, including causing atmospheric warming ( $\mathrm{Xu}$ et al., 2016; Ramanathan and Carmichael, 2008; Lau et al., 2010; Ji et al., 2015), promoting HTP glacial retreat (Xu et al., 2009; Qu et al., 2014; Li et al., 2017; Zhang et al., 2017b; Ming et al., 2009, 2013), altering monsoon system evolution (Bollasina et al., 2008) and affecting the fresh water supplies of billions of residents across Asia. To date, numerous studies have been conducted on the BC concentrations in the atmosphere (Zhao et al., 2013b; Ming et al., 2010; Cong et al., 2015; Marinoni et al., 2010; Wan et al., 2015) and atmospheric BC deposition as determined from lake core sediments (Han et al., 2015; Cong et al., 2013). However, all of these studies exhibit limitations because of certain special environmental factors in the HTP (e.g., high concentrations of mineral dust (MD) in aerosols and catchment inputs to lake core sediment). Therefore, the above studies should be reinvestigated to better define the actual BC values in the HTP. Therefore, in this article, we discussed the actual concentrations and deposition of $\mathrm{BC}$ in the HTP based on data of aerosols collected at two remote stations and previously reported BC deposition data.

At present, the thermal-optical method is a widely used method for measuring BC concentrations in aerosols from the HTP (Zhao et al., 2013b; Ming et al., 2010; Cong et al., 2015; Li et al., 2016d). An important factor influencing the accurate measurement of BC concentrations via this method is the presence of carbonates (inorganic carbon - IC) in MD. IC can also emit $\mathrm{CO}_{2}$ in response to increasing temperature during measurements, thus causing an overestimation of the total carbon (TC) in carbonaceous aerosols (CAs) (Karanasiou et al., 2011). Hence, IC is generally excluded in CA studies (Bond et al., 2013). However, few studies of the HTP have considered the contributions of IC to TC and $\mathrm{BC}$ because one study concluded that IC can be neglected in studies of the TC and BC in midlatitude aerosols because the IC exists at far lower concentrations relative to TC and BC (Chow and Watson, 2002).

This conclusion cannot be blindly applied to other areas because of the complexities of midlatitude environments around the world (e.g., arid areas and deserts with intense dust storm events). For example, previous studies in Xi'an, midwestern and northeastern China showed that IC accounts for approximately $8 \%$ (Cao et al., 2005) to $10 \%$ (Ho et al., 2011) of the TC in particles with diameters less than $2.5 \mu \mathrm{m}$ $\left(\mathrm{PM}_{2.5}\right)$ during dust storm events. Similar phenomena have also been found for both $\mathrm{PM}_{2.5}$ and total suspended particle (TSP) samples in southern Europe (Sillanpää et al., 2005; Perrone et al., 2011). Because TSP samples contain more $\mathrm{MD}$ and carbonates than $\mathrm{PM}_{2.5}$, they should have higher concentrations of IC.

The above phenomenon should also be taken into consideration in the study of CAs of the HTP. Similar to northern China, large sand dunes and deserts are widely distributed across the western HTP (Liu et al., 2005), and dust storms occur frequently in winter and spring (Wang et al., 2005). Thus, IC may account for a large portion of the CAs in the HTP. Unfortunately, the potential contributions of IC to the TC and BC in HTP aerosols have been overlooked (Cao et al., 2010; Cong et al., 2015; Li et al., 2016b; Ming et al., 2010; Wan et al., 2015; Zhao et al., 2013b). Additionally, IC contributions may be high because almost all of the reported data on CAs are based on the TSP content, which includes large volumes of coarse particles derived directly from MD. Therefore, the TC and BC concentrations in the HTP are likely overestimated. In fact, some published articles on aerosols collected from remote areas of the HTP have identified MD components (Cong et al., 2015; Zhao et al., 2013b), although neither of these two studies have directly discussed this issue or evaluated the effects of IC.

Because MD has lower influences on light than $\mathrm{BC}$ in the atmosphere (Clarke et al., 2004; Bond and Bergstrom, 2006) and on glacier surfaces (Qu et al., 2014), considering IC as $\mathrm{BC}$ will overestimate the BC-driven climate forcing. Organic carbon (OC) is generally considered to scatter sunlight. However, some components of OC also absorb sunlight and warm the atmosphere (Andreae and Gelencser, 2006). Therefore, the contributions of IC to the OC and BC values in HTP aerosols must be quantitatively evaluated. In this study, TSP samples from two remote stations in the HTP were collected to evaluate the contributions of IC to the TC and BC. Additionally, seasonal variations in the extent of the overestimations of TC and BC and possible causes were also examined. Finally, previously published TC and BC concentrations at these two stations were adjusted (Cong et al., 2015; Zhao et al., 2013a).

$\mathrm{BC}$ deposition is closely related to the $\mathrm{BC}$ transport processes, lifetime and radiative forcing. Depositional value can be measured from historical media, such as sediments (Gustafsson and Gschwend, 1998; Han et al., 2016) and ice cores (Ming et al., 2007; Ruppel et al., 2014), estimated from BC concentrations in the atmosphere (Jurado et al., 2008) or calculated using models (Zhang et al., 2015). At present, the BC deposition process remains poorly quantified in the HTP because of its complex terrain and dynamic regimes (Bond et al., 2013; Bauer et al., 2013). Thus far, only three studies have directly reported on BC deposition in the HTP. One model indicated that the $\mathrm{BC}$ deposition in the central HTP 


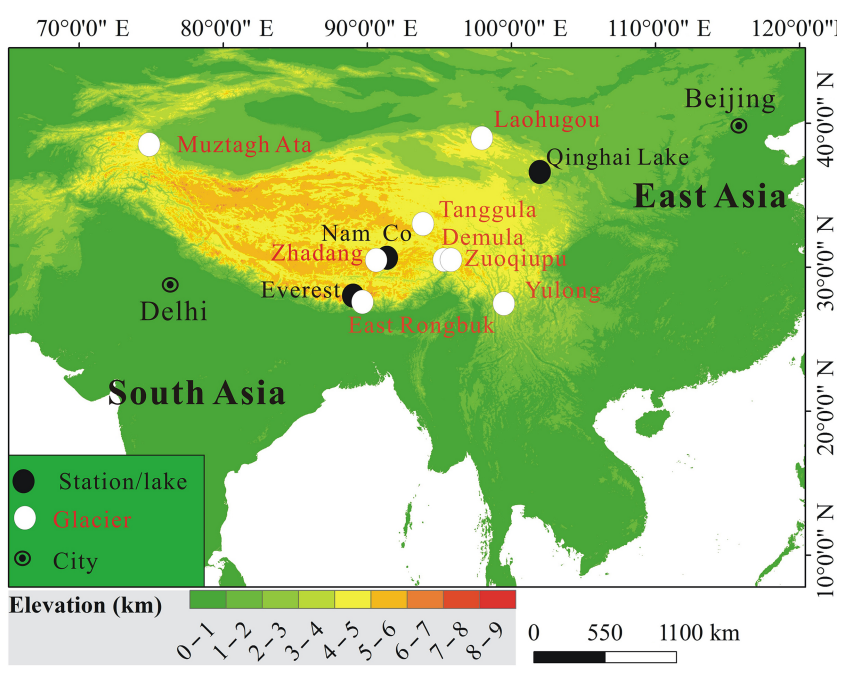

Figure 1. Selected study sites, including the HTP stations, lakes and glaciers.

was $9 \mathrm{mg} \mathrm{m}^{-2} \mathrm{a}^{-1}$ (Zhang et al., 2015), which is approximately 30 times lower than the values measured in lake cores at Nam Co and Qinghai lakes (270-390 $\mathrm{mg} \mathrm{m}^{-2} \mathrm{a}^{-1}$ ) (Fig. 1) (Cong et al., 2013; Han et al., 2011). Although considerable uncertainties exist in atmospheric BC deposition estimated from models (Koch et al., 2009; Bond et al., 2013) and lake core sediments (Yang, 2015; Cohen, 2003), these large differences need to be thoroughly investigated.

For instance, although the influence of sediment focusing on $\mathrm{BC}$ deposition in lake cores has been noted in other areas (Yang, 2015; Blais and Kalff, 1995), it has not been pointed out and evaluated in the HTP. Consequently, correcting for this process might result in incorrect data and explanations. Therefore, additional studies must be performed to provide more reliable $\mathrm{BC}$ deposition values. For instance, other researchers have reported $\mathrm{BC}$ concentrations and water accumulation rates in ice cores and snow pits from the HTP (Fig. 1) (Xu et al., 2009; Li et al., 2016a, c; Ming et al., 2008). Although these studies did not report BC deposition values directly, $\mathrm{BC}$ deposition rates could be easily calculated from the data reported in those articles. Because the cols of glaciers where the snow and ice samples were collected are generally located at the highest altitudes of a given region, $\mathrm{BC}$ is only deposited via wet and dry deposition from the atmosphere. Therefore, these data need to be comprehensively evaluated.

Notably, some uncertainties exist in the comparison of BC data among different studies. Despite recent technological achievements, accurately measuring $\mathrm{BC}$ concentrations in ambient samples remains a challenge in atmospheric chemistry research (Andreae and Gelencser, 2006; Bond et al., 2013; Lim et al., 2014). Because the methods used to measure $\mathrm{BC}$ concentrations and determine $\mathrm{BC}$ deposition levels are not the same, uncertainties will be introduced when directly comparing the results from different studies. For instance, different thermal-optical methods with different temperature increase protocols (e.g., NIOSH vs. IMPROVE vs. EUSAAR_2) will produce different BC concentrations for the same sample (Karanasiou et al., 2015; Andreae and Gelencser, 2006). In general, BC concentrations derived from the IMPROVE method are 1.2-1.5 times higher than those derived from the NIOSH method (Chow et al., 2001; Reisinger et al., 2008), and BC concentrations from the EUSAAR_2 temperature protocol are approximately twice as high as those derived from the NIOSH protocol (Cavalli et al., 2010). Furthermore, lake core samples need to be pretreated with $\mathrm{HCl}$ and hydrofluoric acid (HF) several times prior to measurements with the thermal-optical methods (Han et al., 2015). However, because of the complex chemical properties of ambient samples, the "best" thermaloptical protocol has not been identified (Karanasiou et al., 2015), and an exact ratio for BC produced from different methods is difficult to determine. Therefore, although the direct comparison of $\mathrm{BC}$ concentrations and deposition levels across different studies presents certain uncertainties in this study, the comparison between data of lake core and snow pit is still reliable because $\mathrm{BC}$ deposition of the former was much higher (approximately 20 times) than that of the latter, up to 7 times more among different methods (Watson et al., 2005). For instance, although large uncertainties exist for $\mathrm{BC}$ concentrations within the same environmental matrix (Watson et al., 2005; Hammes et al., 2007; Han et al., 2011), the similarity of the BC deposition values among different glaciers (Table 1) in different studies implies that comparing $\mathrm{BC}$ deposition data is feasible for the glacial region in the HTP. In addition, because BC concentrations measured via the SP2 method are far lower than those measured via thermal-optical methods (Lim et al., 2014) (the former can only measure BC in grain sizes finer than $500 \mathrm{~nm}$; Kaspari et al., 2011), SP2-based BC data were avoided in this study.

\section{Methods}

\subsection{Collection of aerosols, surface soils and river sediments}

TSP samples were collected from the Nam Co Monitoring and Research Station for Multisphere Interactions and the Qomolangma Atmospheric and Environmental Observation and Research Station (Everest station) (Fig. 1) from 2014 to 2016. The Nam Co station is located in the center of the HTP. The Everest station is located on the northern slopes of the Himalayas. Both of these two stations are generally considered to be located in remote areas of the HTP that receive BC transported over long distances from south Asia, and several BC studies have been conducted there (Chen et al., 2015; Cong et al., 2015; Ming et al., 2010; Li et al., 2016a). In detail, TSP samples were collected using $90 \mathrm{~mm}$ pre-combusted 
Table 1. Monitored or recovered BC deposition $\left(\mathrm{mg} \mathrm{m}^{-2} \mathrm{a}^{-1}\right)$ from the HTP and other regions of the world.

\begin{tabular}{llrlr}
\hline Region & Sites & Deposition & Period & References \\
\hline Tibet & Zuoqiupu glacier & 12 & $1970-2005$ & 1 \\
& Muztagh Ata & 18 & $1970-2005$ & 1 \\
& East Rongbuk ice core & 10.2 & $1995-2002$ & 2 \\
& Laohugou glacier & 25 & $2013-2014$ & 3,4 \\
& Tanggula glacier & 21.2 & $2013-2014$ & 3,4 \\
& Zhangdang glacier & 22.8 & $2013-2014$ & 3,4 \\
& Demula glacier & 14.4 & $2013-2014$ & 3,4 \\
& Yulong glacier & 20.3 & $2013-2014$ & 3,4 \\
& Model results of central Tibetan Plateau & 9 & $2013-2014$ & 5 \\
& Nam Co Lake core & 260 & $1960-2009$ & 6 \\
& Qinghai Lake core & $270-390$ & $1770 s-2011$ & 7 \\
& Aerosol of Nam Co station & 10.5 & $2005-2007$ & 8 \\
& Aerosol of Qinghai Lake & 92.7 & $2011-2012$ & 8 \\
\hline \multirow{2}{*}{ East China } & Chaohu lake core, East China & 1160 & $1980-2012$ & 9 \\
& Northern China & 1660 & Around 2010 & 10 \\
& North China Plain & 1500 & $2008-2009$ & 11 \\
\hline
\end{tabular}

Note: 1: Bauer et al. (2013); 2: BC concentration $\left(20.3 \mathrm{ng} \mathrm{g}^{-1}\right)$ and snow accumulation $(500 \mathrm{~mm})$ were adopted from Ming

et al. (2008) and Li et al. (2016c), respectively; 3: Li et al. (2016c); 4: Li et al. (2016a); 5: Zhang et al. (2015); 6: Cong et al. (2013);

7: Han et al. (2015); 8: calculated in this study; 9: Han et al., (2016); 10: Fang et al. (2015); 11: Tang et al. (2014).

Table 2. Precipitation $(\mathrm{mm})$ and $\mathrm{BC}$ concentration $\left(\mathrm{ng} \mathrm{m}^{-3}\right)$ values used for the $\mathrm{BC}$ deposition calculations for Nam Co Lake and Qinghai Lake.

\begin{tabular}{lrrrr}
\hline & $\begin{array}{c}\text { Nam Co Lake } \\
\text { precipitation }\end{array}$ & BC concentration & $\begin{array}{c}\text { Qinghai Lake } \\
\text { precipitation }\end{array}$ & BC concentration \\
\hline Spring & 29.65 & 135.86 & 77.51 & 1000 \\
Summer & 190.05 & 90.97 & 244.02 & 530 \\
Autumn & 79.72 & 86.58 & 89.78 & 690 \\
Winter & 2.95 & 93.55 & 3.81 & 1050 \\
\hline
\end{tabular}

$\left(550^{\circ} \mathrm{C}, 6 \mathrm{~h}\right)$ quartz fiber filters (Whatman Corp) with a vacuum pump (VT 4.8, Germany). Because the pump was not equipped with a flow meter, the air volumes passing through each filter could not be determined (Li et al., 2016d); however, this did not influence the objectives of this study (e.g., relative concentrations of TC and $\mathrm{BC}$ in the original and acidtreated samples). Four field blank filters were also collected from each station by exposing the filters in each sampler without pumping.

To compare the BC concentrations of the Nam Co Lake cores, two surface soil samples and four suspended particle samples from four rivers in the Nam Co Basin were collected during a period of peak river flow in 2015. The $<20 \mu \mathrm{m}$ fraction of these samples was extracted (Li et al., 2009) and treated (Han et al., 2015) to measure the BC concentrations. In addition, 10 surface soil samples around the Everest station were collected to study the $\mathrm{pH}$ values.

\subsection{Measurement of BC and elemental concentrations}

The carbonates of the collected aerosol samples were removed via a fumigation process involving exposing a subset of samples to a vapor of $37 \%$ hydrochloric acid $(\mathrm{HCl})$ for $24 \mathrm{~h}$. Then, the treated samples were held at $60^{\circ} \mathrm{C}$ for over $1 \mathrm{~h}$ to remove any acid remaining on the filter (Li et al., 2016a; Pio et al., 2007; Chen et al., 2013; Bosch et al., 2014). The OC and elemental carbon (EC, the common chemical/mass definition of $\mathrm{BC}$ ) concentrations of both the original and treated samples were measured using a Desert Research Institute (DRI) model 2001 thermal-optical carbon analyzer (Atmoslytic Inc., Calabasas, CA, USA) following the IMPROVE-A protocol (Chow and Watson, 2002). The OC and BC concentrations were determined based on varying transmission signals. To investigate the $\mathrm{BC}$ concentration measured by different methods, 16 acid-fumigated aerosol samples were measured following the EUSAAR_2 and NIOSH protocols for comparison with the results of the IMPROVE protocol. The results showed that the TC concentrations of three methods for the 
same sample were similar, as suggested by previous research (Chow et al., 2001). The ratios of $\mathrm{BC}_{(\mathrm{IMPROVE})} / \mathrm{BC}_{(\mathrm{NIOSH})}$ and $\mathrm{BC}_{\left(\mathrm{EUSAAR}_{2}\right)} / \mathrm{BC}_{(\mathrm{NIOSH})}$ for the studied samples were $1.36 \pm 0.35$ and $1.88 \pm 0.60$, respectively, both of which agreed with the previously proposed ratios of 1.2-1.5 (Chow et al., 2001; Reisinger et al., 2008) and 2 (Cavalli et al., 2010), respectively. To evaluate the concentrations of MD, the concentrations of $\mathrm{Ca}, \mathrm{Fe}, \mathrm{Al}$ and $\mathrm{Ti}$ in the aerosol samples were measured by inductively coupled plasma optical emission spectroscopy (ICP-OES) following the method of Li et al. (2009). All the reported values in this study were corrected based on the values of the blanks. The contributions of MD (Maenhaut et al., 2002) and CA (Ram et al., 2010) of the collected samples were calculated using the following equations:

$$
\begin{aligned}
& \mathrm{MD}=(1.41 \times \mathrm{Ca}+2.09 \times \mathrm{Fe}+1.9 \times \mathrm{Al}+2.15 \times \mathrm{Si} \\
& +1.67 \times \mathrm{Ti}) \times 1.16
\end{aligned}
$$

where $\mathrm{Si}$ is calculated from $\mathrm{Al}$ assuming an average ratio of $\mathrm{Si} / \mathrm{Al}$ is 2.5 (Carrico et al., 2003), and

$\mathrm{CA}=\mathrm{OC} \times 1.6+\mathrm{BC}$.

\subsection{Adoption and calculation of BC deposition data}

To determine the actual BC deposition in the HTP, previously reported data were compiled and evaluated (Table 1). In addition, $\mathrm{BC}$ deposition rates from the Nam Co station and Qinghai Lake basin were estimated from the average BC concentrations in the atmosphere and average precipitation levels using the method described in detail in other studies (Jurado et al., 2008; Fang et al., 2015) (Table 2). In brief, the annual atmospheric deposition rate of $\mathrm{BC}\left(\mu \mathrm{g} \mathrm{m}^{-2} \mathrm{a}^{-1}\right)$ was calculated as follows:

$$
\begin{aligned}
& F_{\mathrm{BC}}=F_{\mathrm{DD}}+F_{\mathrm{WD}} \\
& F_{\mathrm{DD}}=7.78 \times 10^{4} \cdot V_{\mathrm{D}} \cdot \mathrm{C}_{\mathrm{BC}-\mathrm{TSP}} \\
& F_{\mathrm{WD}}=10^{-3} \cdot P_{0} \cdot W_{\mathrm{p}} \cdot \mathrm{C}_{\mathrm{BC}-\mathrm{TSP}},
\end{aligned}
$$

where $F_{\mathrm{DD}}$ and $F_{\mathrm{WD}}$ are the seasonal dry and wet deposition $\left(\mu \mathrm{g} \mathrm{m}^{-2}\right)$, respectively; $V_{\mathrm{D}}, P_{0}$ and $W_{\mathrm{p}}$ are the dry deposition velocity of aerosol $\left(0.15 \mathrm{~cm} \mathrm{~s}^{-1}\right)$, the precipitation amount $(\mathrm{mm})$ in a given season and the particle washout ratio $\left(2.0 \times 10^{5}\right)$, respectively (Fang et al., 2015); and $\mathrm{C}_{\mathrm{BC}-\mathrm{TSP}}$ is the BC concentration of the TSPs $\left(\mu \mathrm{g} \mathrm{m}^{-3}\right)$. The seasonal BC concentrations at the Nam Co station were monitored with an AE-31, and the average precipitation levels at the station were recorded from 2014-2015. The BC concentrations in Qinghai Lake are reported in Zhao et al. (2015), and the average 1961-2010 precipitation levels recorded by the China Meteorological Administration from the Huangyuan station in the lake basin were used. The values used in the BC deposition calculations for these two areas are shown in Table 2.

\section{Results and discussion}

\subsection{Actual BC concentrations in the atmosphere over the HTP}

\subsubsection{Contribution of carbonate carbon to both TC and BC}

In this study, it was shown that carbonate carbon significantly contributes to the $\mathrm{BC}$, TC and $\mathrm{OC}$ concentrations of the TSP samples of Nam Co and Everest stations after comparing $\mathrm{BC}$ and $\mathrm{OC}$ concentrations between original and acidtreated samples. The ratios of the $\mathrm{TC}, \mathrm{OC}$ and $\mathrm{BC}$ levels of the aerosols treated with acid $\left(\mathrm{TC}_{\mathrm{A}}, \mathrm{OC}_{\mathrm{A}}\right.$ and $\left.\mathrm{BC}_{\mathrm{A}}\right)$ to those of the original samples $\left(\mathrm{TC}_{\mathrm{O}}, \mathrm{OC}_{\mathrm{O}}\right.$ and $\mathrm{BC}_{\mathrm{O}}$ ) were $0.81 \pm 0.13,0.78 \pm 0.10$ and $0.48 \pm 0.35$, respectively, for the Nam Co station and $0.76 \pm 0.12,0.78 \pm 0.12$ and $0.61 \pm 0.24$, respectively, for the Everest station. Meanwhile, because of heavy precipitation during monsoon period, influences of IC to both $\mathrm{BC}$ and TC during this time were lower than those of non-monsoon period at two studied stations (Fig. 2). As proposed in previous work (Chow and Watson, 2002), BC concentrations are more heavily influenced than OC and TC concentrations because carbonates are more prone to decompose at high temperatures along with $\mathrm{BC}$ during analyses. The $\mathrm{OC}$ concentrations in the treated samples used in this study also decreased, indicating that carbonates can also decompose at low temperatures (Karanasiou et al., 2011). Clear seasonal variations, i.e., low $\mathrm{TC}_{\mathrm{A}} / \mathrm{TC}_{\mathrm{O}}$ ratios during non-monsoon periods and high $\mathrm{TC}_{\mathrm{A}} / \mathrm{TC}_{\mathrm{o}}$ ratios during monsoon periods, were observed in the aerosols at the Nam Co station (Fig. 2). This pattern is consistent with the intense dust storms that occur during non-monsoon periods. However, clear seasonal patterns in the $\mathrm{TC}_{\mathrm{A}} / \mathrm{TC}_{\mathrm{o}}$ ratio at the Everest station were not observed, in accordance with the relatively stable seasonal variations in the $\mathrm{Ca}^{2+}$ content in aerosols recorded at this station (Cong et al., 2015). To evaluate the relative ratio of $\mathrm{MD}$ and $\mathrm{CA}, \mathrm{MD} /(\mathrm{MD}+\mathrm{CA})$ values were calculated (Fig. 3). The $\mathrm{MD} /(\mathrm{MD}+\mathrm{CA}$ ) levels recorded at the Nam Co station during non-monsoon periods were significantly higher than those recorded during monsoon periods $(p<0.01)$, whereas the corresponding values at the Everest station were not significantly different between the two periods $(p>0.05)$ (Fig. 3). Compared with those of other areas, the $\mathrm{MD} /(\mathrm{MD}+\mathrm{CA})$ values recorded at the two stations were higher than those recorded at the NCO-P station $\left(27.95^{\circ} \mathrm{N}, 86.82^{\circ} \mathrm{E} ; 5079\right.$ m.a.s.1) (70 and $73 \%$ for the premonsoon and monsoon periods, respectively) located on the southern slope of the Himalayas (Decesari et al., 2010). This difference may be related to the serious levels of south Asian pollutants at the NCO-P station and the relative ease with which polluted clouds are transported to this station. However, because the measured particle size $\left(\mathrm{PM}_{10}\right)$ and the measurement methods of $\mathrm{Ca}, \mathrm{Mg}$ and $\mathrm{EC}$ at the NCO-P station 

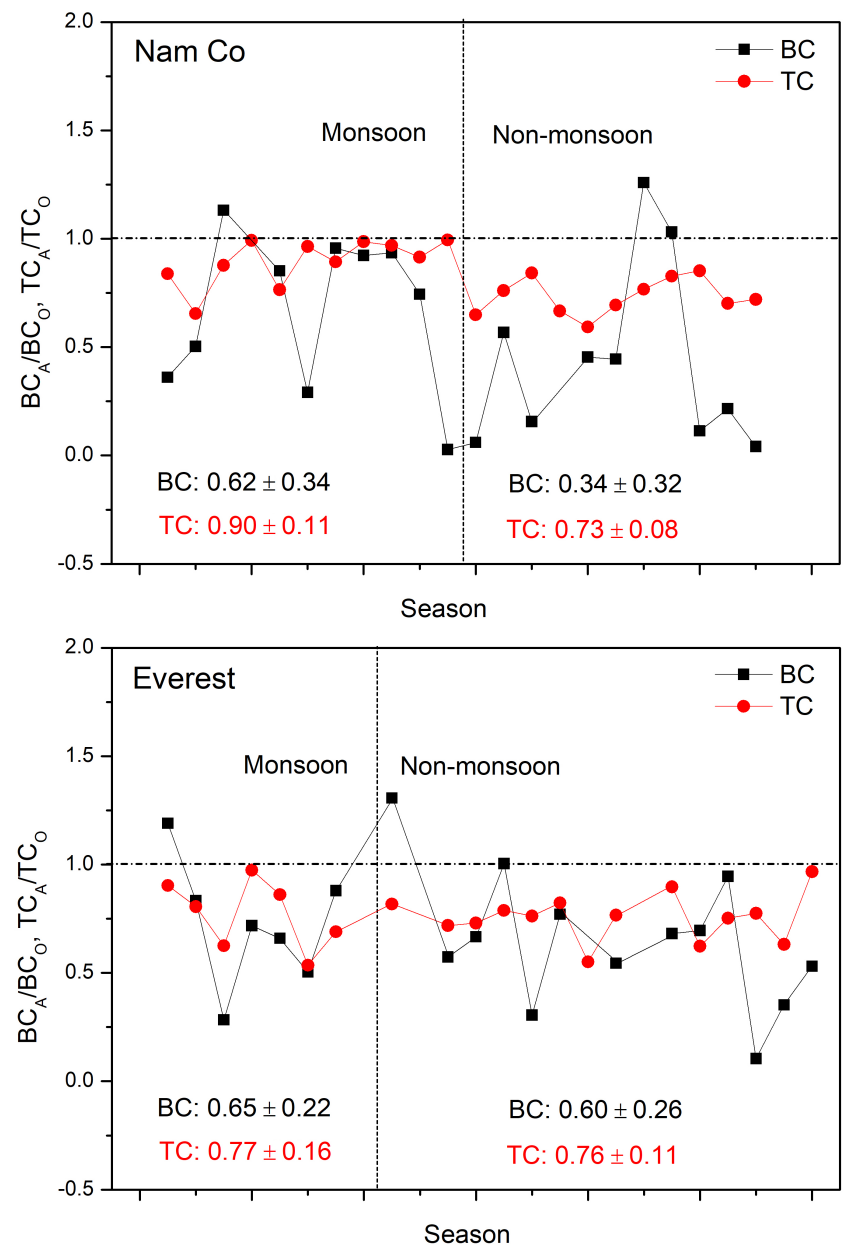

Figure 2. Seasonal variations in the $\mathrm{BC}$ and $\mathrm{TC}$ concentrations in the original and acid-treated aerosol samples collected at the Nam Co and Everest stations.

differed from those in this study, uncertainties exist in such a direct comparison.

The Everest station is located in a dry river valley with sparse vegetation cover (a typical barren site), and the MD derived from the local surface soil contributes considerably to aerosols collected during monsoon periods (Liu et al., 2017). However, the Nam Co station is located in a typical grassland region with limited amounts of locally sourced dust during monsoon periods. Additionally, the Everest station is located in the rain shadow of the Himalayas; thus, the precipitation level recorded at the Everest station $(172 \mathrm{~mm}$ during the monsoon period between 2014 and 2015) is much lower than that at the Nam Co station $(258 \mathrm{~mm})$, causing high MD concentrations in the atmosphere of the Everest station during that period. Potential carbonate-induced biasing of aerosol samples has been proposed to occur in arid areas with alkaline soils (Chow and Watson, 2002). Because of the dry weather conditions, the $\mathrm{pH}$ values of the soil around the Nam Co and Everest stations are as high as 8 ( $\mathrm{Li}$ et al.,
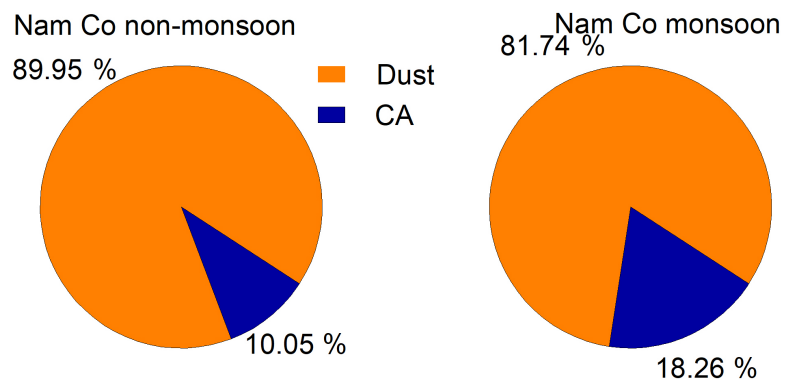

Everest non-monsoon

Everest monsoon
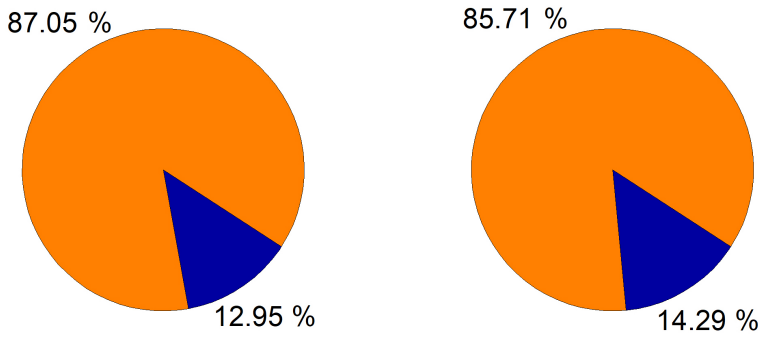

Figure 3. Percentage of $\mathrm{MD}$ and $\mathrm{CA}$ relative to their sum during both non-monsoon and monsoon periods at the Nam Co and Everest stations.

2008) and 8.3, respectively, implying considerable carbonate contributions. During non-monsoon periods, MD is mainly transported by westerlies from the arid western HTP, where MD is distributed across large deserts with sand dunes; thus, the aerosol samples were influenced by MD with high concentrations of carbonates. Finally, the significant positive relationship $(p<0.01)$ between $\mathrm{Ca}$ and $\mathrm{IC}\left(\mathrm{TC}_{\mathrm{O}}-\mathrm{TC}_{\mathrm{A}}\right)$ for the aerosols of these two stations further demonstrated the contributions of $\mathrm{CaCO}_{3}$ to aerosol IC (Fig. 4). The ratio of $\mathrm{Ca} / \mathrm{IC}$ was higher in the Everest station samples than that of Nam Co station, possibly reflecting different types of carbonate at these two stations.

\subsubsection{Actual BC concentrations at the two stations and implications}

In summary, we clearly showed that the presence of carbonates in MD led the TC levels in TSP samples in the HTP to be overestimated by approximately $19 \pm 13$ and $24 \pm 12 \%$ at the Nam Co and Everest stations, respectively. These overestimates were higher than the corresponding value of $10 \%$ found for coarse particles in the central Mediterranean region of Europe (Perrone et al., 2011). In addition, the related $\mathrm{BC}$ values were overestimated by approximately $52 \pm 35$ and $39 \pm 24 \%$, respectively, thus implying that the actual BC concentrations at these two stations were lower than previously reported values. Although fumigation with $\mathrm{HCl}$ can cause the loss of volatile organic acids in treated samples (Chow et al., 1993), this potential influence is not important because of the significant relationship between $\mathrm{TC}_{\mathrm{O}}-\mathrm{TC}_{\mathrm{A}}$ and $\mathrm{Ca}$ (Fig. 4). Moreover, because of the large variations in the above val- 

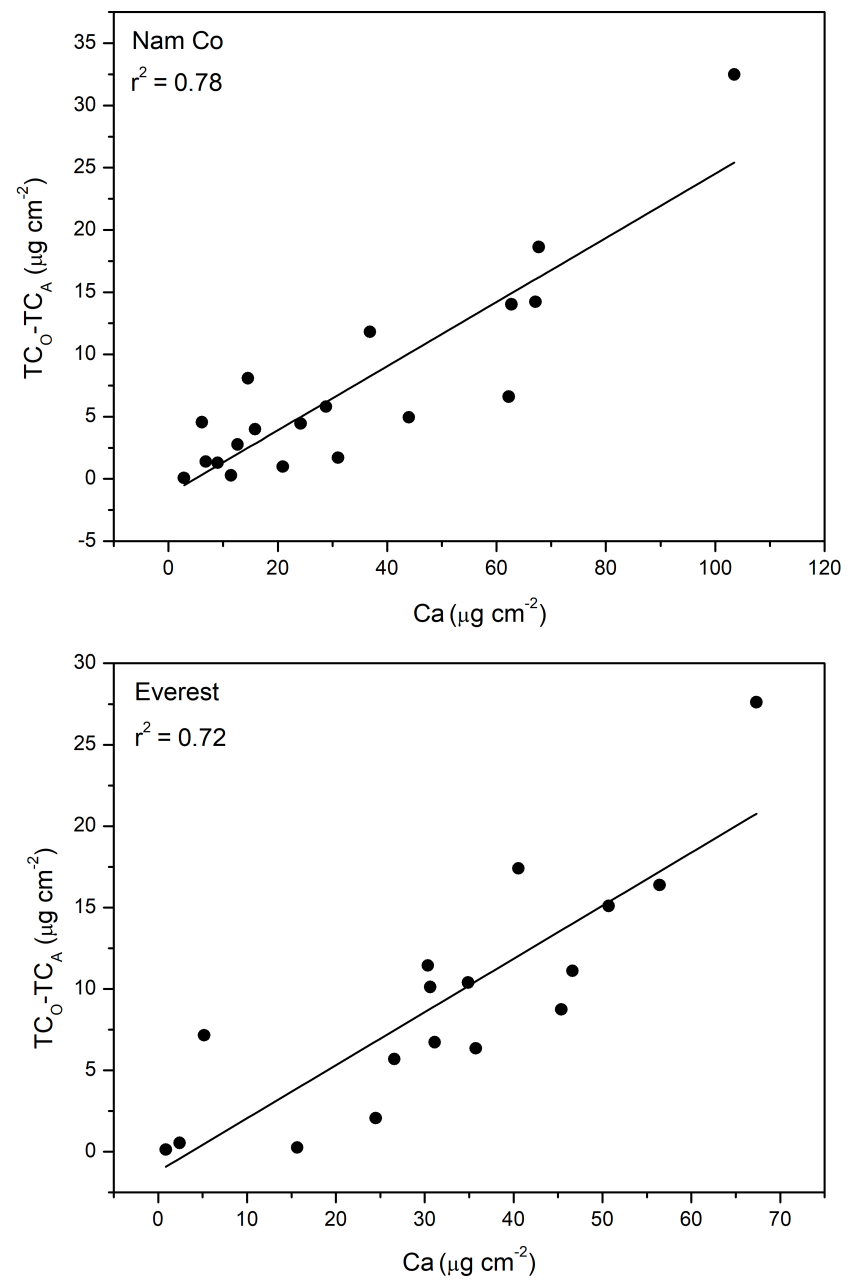

Figure 4. Relationship between aerosol IC and $\mathrm{Ca}$ at the Nam Co and Everest stations.

ues, the corrected $\mathrm{BC}$ concentrations at the two stations have large uncertainties. Therefore, based on previously reported $\mathrm{BC}$ concentrations measured via the same method as in this study (Zhao et al., 2013a; Cong et al., 2015), the actual BC concentrations at the Nam Co and Everest stations were estimated to be 61 and $154 \mathrm{ng} \mathrm{m}^{-3}$, respectively.

Carbonates can decompose at relatively low temperatures during measurement, leading to overestimation of both BC and OC concentrations (Karanasiou et al., 2011). In addition, sometimes the acid-treated ambient samples transfer some components of $\mathrm{OC}$ to $\mathrm{BC}$, leading to higher $\mathrm{BC}$ concentrations (Jankowski et al., 2008). However, this phenomenon was not common in the aerosol samples examined in this study, although several samples from both stations showed higher $\mathrm{BC}$ concentrations in the acid-treated samples (Fig. 2). Because $\mathrm{BC}_{\mathrm{A}}$ cannot be higher than $\mathrm{BC}_{\mathrm{O}}$, the samples with $\mathrm{BC}_{\mathrm{A}} / \mathrm{BC}_{\mathrm{O}}$ values greater than 1 were not included in the above calculations. Nevertheless, the ratio of $\mathrm{BC}_{\mathrm{A}} / \mathrm{BC}_{\mathrm{O}}$ was considered to be slightly overestimated, as some por- tion of $\mathrm{OC}$ was considered $\mathrm{BC}$ in the acid-treated samples (Jankowski et al., 2008).

Since the influence of carbonate carbon on TC has been observed in $\mathrm{PM}_{2.5}$ samples from Qinghai Lake, northwest China (Zhao et al., 2015), this phenomenon should be obvious in the TSP samples in this study. Because dust storms in the northern and western parts of the HTP are more severe than those near the two studied stations during the nonmonsoon periods, the effect of carbonates on the concentrations of $\mathrm{OC}$ and $\mathrm{BC}$ should be more pronounced in such areas and must be seriously considered in future studies. Therefore, the overestimation of $\mathrm{BC}$ values is likely greater in the northern and western parts of the HTP than near Nam Co, as we noted previously. MD concentrations have been shown to be much higher than $\mathrm{BC}$ concentrations in snow and ice core samples from the HTP (Qu et al., 2014; Li et al., 2017). However, numerous studies have measured BC concentrations without using an acid pretreatment step (Qu et al., 2014; Li et al., 2017; Zhang et al., 2017b). Therefore, the contribution of carbonates in MD to the BC concentrations in snow and ice core samples is likely considerable and needs to be quantitatively evaluated in a future study. Similarly, related HTP studies on other issues, such as BC radiative forcing and atmospheric transport models, based on in situ BC concentrations must be adjusted.

\subsection{Actual BC deposition in the HTP}

\subsubsection{Overestimated $\mathrm{BC}$ deposition in lake cores from the HTP}

In general, the $\mathrm{BC}$ deposition levels measured via different methods should be consistent for a given region. For instance, in the severely polluted region of eastern China (Chen et al., 2013; Yan et al., 2015), the BC deposition rate recovered from a Chaohu lake core was $1660 \mathrm{mg} \mathrm{m}^{-2} \mathrm{a}^{-1}$ (Han et al., 2016), which was close to the values of northern China calculated from the BC concentrations in aerosols (Fang et al., 2015) and determined via in situ monitoring on the North China Plain (Tang et al., 2014) (Table 1). However, this consistency was not the case in the HTP, where large discrepancies were found among the reported HTP BC deposition values. Catchment inputs have been shown to significantly influence the chemical deposition values reconstructed from lake cores (Yang, 2015). For instance, BC deposition rates derived from lake cores of Nam Co Lake (NMC09) and Qinghai Lake were 260 and $270-390 \mathrm{mg} \mathrm{m}^{-2} \mathrm{a}^{-1}$, respectively, which were much higher than those derived from ice core and snow pit samples from the HTP (Table 1). We proposed that the $\mathrm{BC}$ deposition in the lake cores of Qinghai Lake mainly reflected atmospheric deposition followed by catchment inputs. However, the NMC09 value of Nam Co Lake was mainly influenced by catchment inputs.

Lake-core-derived BC deposition in Qinghai Lake was only 2-3 times higher than that estimated from the $\mathrm{BC}$ con- 


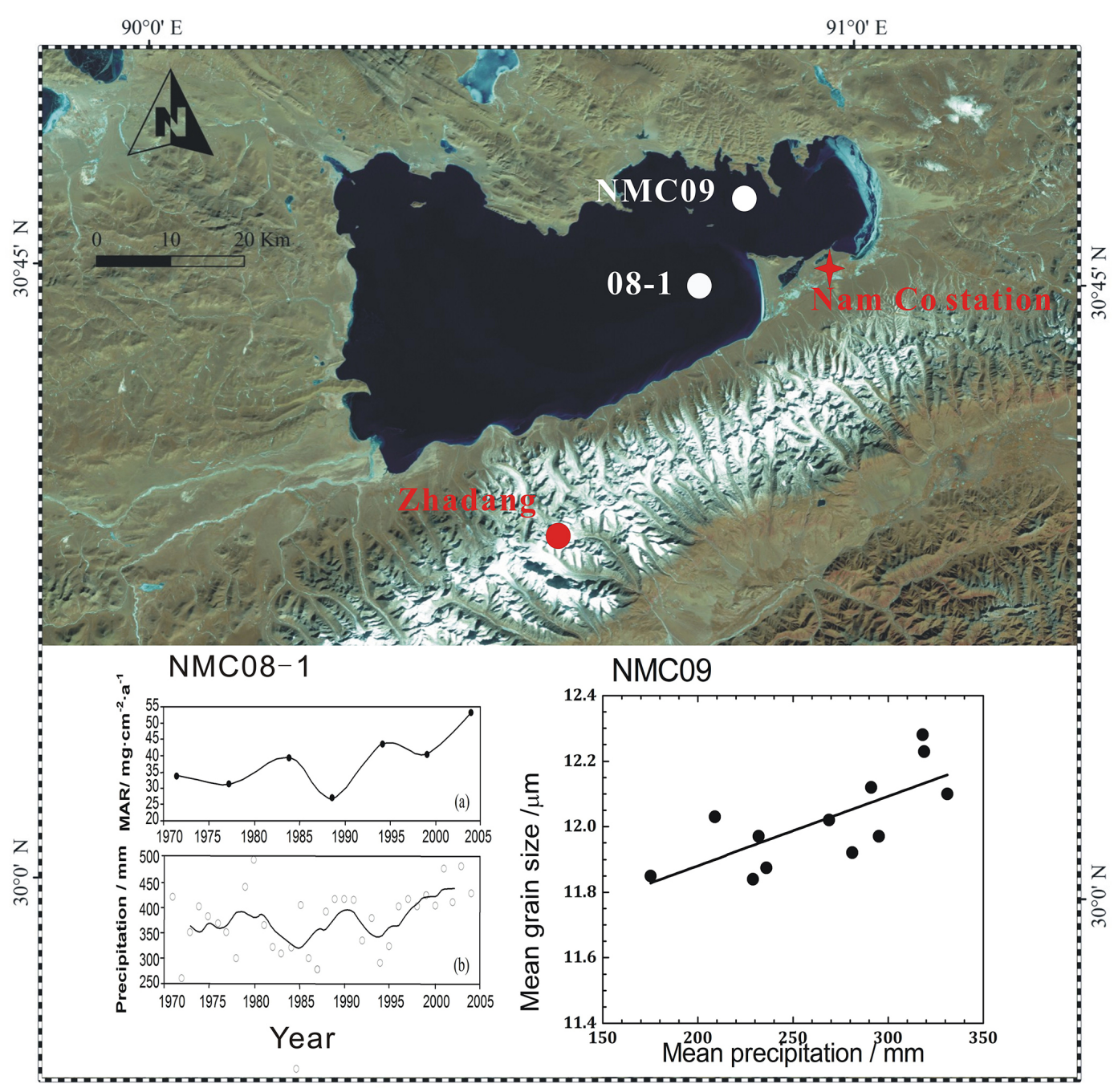

Figure 5. Similar variations in precipitation and mass accumulation rates (a) (Wang et al., 2011) and significant relationships between mean precipitation and mean grain size (b) (Li et al., 2014) in the Nam Co Lake cores.

centrations of $\mathrm{PM}_{2.5}$ in the atmosphere (Zhao et al., 2015). Because $\mathrm{PM}_{2.5}$ does not include all particles in the atmosphere, the actual BC concentration in the atmosphere should be higher than that of $\mathrm{PM}_{2.5}$ (Li et al., 2016b; Viidanoja et al., 2002); therefore, the atmospheric BC deposition should be more similar to that of a lake core. In addition, a previous study showed that approximately 65 and $22 \%$ of the surface sediments in Qinghai Lake resulted from atmospheric deposition and catchment inputs (Wan et al., 2012), respectively, further demonstrating the significant effects of atmospheric deposition on lake core sediments. Therefore, if the BC deposition from atmospheric particles and that of the lake core are the same, then the atmospheric BC deposition based on Qinghai Lake core data is overestimated by approximately $35 \%$.

Correspondingly, catchment inputs account for a large proportion of the NMC09 samples. BC is widely distributed throughout environmental materials (e.g., soil and river sediments) because of its inert characteristics (Cornelissen et al., 2005; Bucheli et al., 2004). Therefore, river inputs contribute sediments as well as BC to lakes. For instance, in the Nam Co Basin, BC concentrations within the $<20 \mu \mathrm{m}$ fraction of surface soil and sediment reach $0.78 \pm 0.48 \mathrm{mgg}^{-1}$, which is close to the Nam Co Lake core concentration of $0.74 \mathrm{mg} \mathrm{g}^{-1}$ (Cong et al., 2013). In addition, several findings have demonstrated the contributions of catchment inputs to Nam Co Lake cores because of the focusing factor, which was shown in the following sections.

First, a large glacial area $\left(141.88 \mathrm{~km}^{2}\right)$ is present within the Nam Co Basin (Fig. 5), and large volumes of glacier meltwater and sediment flow into the lake annually (Wu et al., 2007). Due to recent increasing temperatures and precipitation in the Nam Co Basin, glacier meltwater accounts for approximately $50.6 \%$ of the lake's volume, which has 


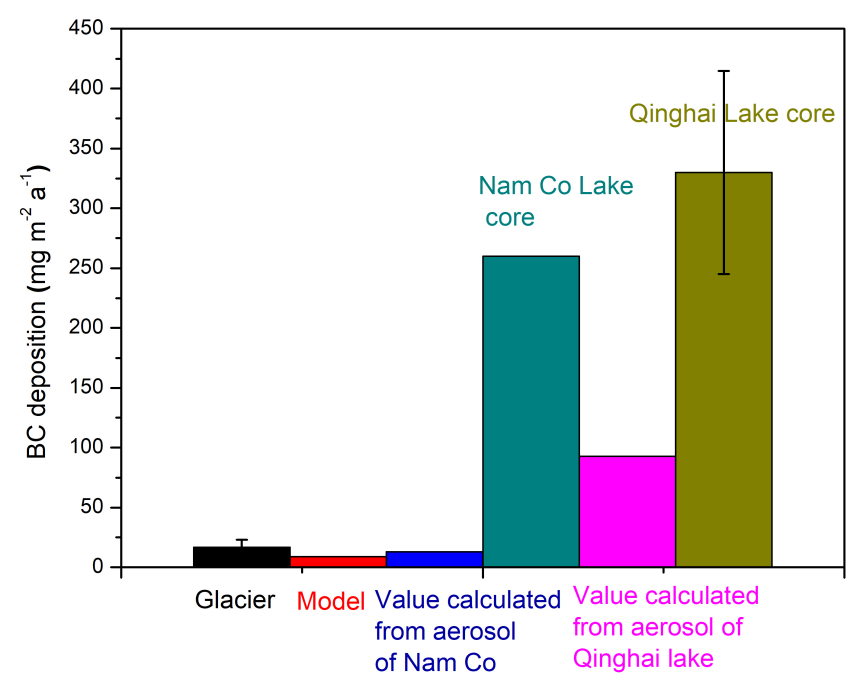

Figure 6. Comparison of atmospheric BC deposition rates derived from the glacial region, models, lake cores and values calculated from BC concentrations in the aerosols of the HTP.

increased over the last 30 years (Zhu et al., 2010). Originating at high-elevation glacier terminal, these rivers flow are at a steep angle, and large volumes of suspended allochthonous sediments are transported into Nam Co Lake annually (Doberschütz et al., 2014). A similar phenomenon was also observed in lake cores of a glacier-fed lake as a result of glacier meltwater effects (Bogdal et al., 2011). Second, previous studies on the accumulation rates in lake cores have revealed significant contributions of riverine particles. The accumulation rates in a Nam Co Lake core (NMC 08-1) are consistent with the precipitation variations recorded in the Nam Co Basin during the last 60 years (Fig. 5a) (Wang et al., 2011), indicating that heavy precipitation promotes the transport of large riverine particles to the lake, thus increasing the accumulation rates in the lake cores. Interestingly, the mean grain size of the lake core (NMC09) that reported BC atmospheric deposition showed a significant positive relationship with precipitation (Fig. 5b), thus reflecting the same relationship between catchment inputs and lake core accumulation rates ( $\mathrm{Li}$ et al., 2014). Because these two lake cores were drilled from different sites (Fig. 5), their similar catchment input characteristics reflect a common feature of Nam Co sediment. As shown above, the BC concentrations in the fine fraction of the river sediments are nearly equivalent to those in the lake cores; thus, additional catchment inputs will increase the $\mathrm{BC}$ deposition rates within lake cores. Third, the atmospheric $\mathrm{BC}$ deposition rate calculated from $\mathrm{BC}$ concentrations in the atmosphere is much lower than the $\mathrm{BC}$ deposition rate recorded in the Nam Co Lake cores (Fig. 6), further reflecting the dominant contributions of catchment inputs relative to atmospheric inputs in lake cores.

The above evidence demonstrates that variations in the $\mathrm{BC}$ deposition in Nam Co Lake mainly reflect variations in catch- ment inputs rather than in atmospheric inputs; thus, atmospheric deposition plays a minor role relative to catchment inputs. Because most lakes in the HTP have increased in area over the last 20 years (Zhang et al., 2017a), this phenomenon likely occurs in many other lakes in the HTP.

\subsubsection{Actual atmospheric BC deposition and potential uncertainties}

$\mathrm{BC}$ deposition rates derived from ice cores and snow pits are proposed to be closer to the actual atmospheric values in the HTP. This hypothesis is supported by two lines of evidence. First, $\mathrm{BC}$ deposition levels in the snow pits of different glaciers are consistent. For example, the estimated BC deposition rates of Laohugou, Tanggula, Zhadang, Demula and Yulong are 25, 21.3, 20, 14.5 and $20.2 \mathrm{mg} \mathrm{m}^{-2} \mathrm{a}^{-1}$, respectively (Table 1 ), which reflects a homogeneous spatial distribution in $\mathrm{BC}$ deposition. The above values are also similar to those of ice cores described in other articles (e.g., 18, 12 and $10.1 \mathrm{mg} \mathrm{m}^{-2} \mathrm{a}^{-1}$ for the Muztagh Ata, Zuoqiupu and east Rongbuk glaciers, respectively (Xu et al., 2009; Bauer et al., 2013; Ming et al., 2008) (Table 1). Second, these values are nearly equivalent to those of atmospheric $\mathrm{BC}$ deposition rates derived from completely different methods (e.g., Community Atmosphere Model version 5 (Zhang et al., 2015) and other models (Bauer et al., 2013) (Table 1). In summary, despite some uncertainties associated with the remote study area, the atmospheric $\mathrm{BC}$ deposition rate of $17.9 \pm 5.3 \mathrm{mg} \mathrm{m}^{-2} \mathrm{a}^{-1}$ in the glacial region of the HTP is proposed.

\section{Conclusions}

The BC concentration and deposition in the HTP region, which features the largest glacial area in the middle latitudes, were investigated and re-evaluated in this article. Our findings indicated that carbonate carbon contributions from MD have led to overestimations of approximately $52 \pm 35$ and $39 \pm 24 \%$ in previously reported BC concentrations in TSP samples at the remote Nam Co and Everest stations, respectively, in the central and southern HTP. After omitting the contributions of carbonate carbon, the actual BC concentrations at the Nam Co and Everest stations should be 61 and $154 \mathrm{ng} \mathrm{m}^{-3}$, respectively. In addition, the levels of OC and TC in TSP samples were also overestimated by $22 \pm 10$ and $19 \pm 13 \%$, respectively, at the Nam Co station and by $22 \pm 12$ and $24 \pm 12 \%$, respectively, at the Everest station. These values of TC were close to those of a study in the western HTP (Cao et al., 2009). Large arid areas that receive little precipitation are distributed across the western and northern HTP; thus, the effects of carbonates on BC measurements are expected to be greater in these areas and must be considered in future related studies. In addition, TSP samples must be treated with acid to eliminate the effects of carbonates prior to measuring $\mathrm{BC}$. A comparison among $\mathrm{BC}$ deposition val- 
ues based on different methods and materials showed that, because of catchment inputs, the $\mathrm{BC}$ deposition rates derived from HTP lake cores were higher than the actual atmospheric deposition values. Correspondingly, the $\mathrm{BC}$ deposition values measured from snow pits and ice cores in glacial regions were similar to those obtained via models; thus, these data reflect the actual atmospheric $\mathrm{BC}$ deposition values. Although the HTP is located adjacent to seriously polluted regions in south Asia and east China, the HTP BC deposition rates are relatively low because of the high elevation. Finally, our results indicate that the atmospheric $\mathrm{BC}$ deposition rate in the HTP is approximately $17.9 \pm 5.3 \mathrm{mg} \mathrm{m}^{-2} \mathrm{a}^{-1}$, with lower and higher values appearing in the central and peripheral areas of the HTP, respectively.

Data availability. All the data reported in this article are available upon request. Please contact the corresponding author (Chaoliu Li, lichaoliu@itpcas.ac.cn).

Competing interests. The authors declare that they have no conflict of interest.

Special issue statement. This article is part of the special issue "Atmospheric pollution in the Himalayan foothills: the SusKat-ABC international air pollution measurement campaign". It is not associated with a conference.

Acknowledgements. This study was supported by the NSFC (41630754, 41675130), the State Key Laboratory of Cryospheric Science (SKLCS-ZZ-2017) and the China Postdoctoral Science Foundation (2016M602897). This study is part of a framework across the HTP: atmospheric Pollution and Cryospheric Change (APCC). Additionally, the authors thank the staff of the Nam Co and Everest stations for collecting samples and providing precipitation data.

Edited by: Ernest Weingartner

Reviewed by: two anonymous referees

\section{References}

Andreae, M. O. and Gelencser, A.: Black carbon or brown carbon? The nature of light-absorbing carbonaceous aerosols, Atmos. Chem. Phys., 6, 3131-3148, https://doi.org/10.5194/acp-63131-2006, 2006.

Bauer, S. E., Bausch, A., Nazarenko, L., Tsigaridis, K., Xu, B., Edwards, R., Bisiaux, M., and McConnell, J.: Historical and future black carbon deposition on the three ice caps: ice core measurements and model simulations from 1850 to 2100 , J. Geophys. Res.-Atmos., 118, 7948-7961, 2013.

Blais, J. M. and Kalff, J.: The influence of lake morphometry on sediment focusing, Limnol. Oceanogr., 40, 582-588, 1995.
Bogdal, C., Bucheli, T. D., Agarwal, T., Anselmetti, F. S., Blum, F., Hungerbühler, K., Kohler, M., Schmid, P., Scheringer, M., and Sobek, A.: Contrasting temporal trends and relationships of total organic carbon, black carbon, and polycyclic aromatic hydrocarbons in rural low-altitude and remote high-altitude lakes, J. Environ. Monitor., 13, 1316-1326, 2011.

Bolch, T., Kulkarni, A., Kääb, A., Huggel, C., Paul, F., Cogley, J. G., Frey, H., Kargel, J. S., Fujita, K., and Scheel, M.: The state and fate of Himalayan glaciers, Science, 336, 310-314, 2012.

Bollasina, M., Nigam, S., and Lau, K. M.: Absorbing aerosols and summer monsoon evolution over South Asia: an observational portrayal, J. Clim., 21, 3221-3239, https://doi.org/10.1175/2007jcli2094.1, 2008.

Bond, T. C. and Bergstrom, R. W.: Light absorption by carbonaceous particles: an investigative review, Aerosol Sci. Tech., 40, 27-67, 2006.

Bond, T. C., Doherty, S. J., Fahey, D. W., Forster, P. M., Berntsen, T., DeAngelo, B. J., Flanner, M. G., Ghan, S., Kaercher, B., Koch, D., Kinne, S., Kondo, Y., Quinn, P. K., Sarofim, M. C., Schultz, M. G., Schulz, M., Venkataraman, C., Zhang, H., Zhang, S., Bellouin, N., Guttikunda, S. K., Hopke, P. K., Jacobson, M. Z., Kaiser, J. W., Klimont, Z., Lohmann, U., Schwarz, J. P., Shindell, D., Storelvmo, T., Warren, S. G., and Zender, C. S.: Bounding the role of black carbon in the climate system: a scientific assessment, J. Geophys. Res.Atmos., 118, 5380-5552, https://doi.org/10.1002/jgrd.50171, 2013.

Bosch, C., Andersson, A., Kirillova, E. N., Budhavant, K., Tiwari, S., Praveen, P., Russell, L. M., Beres, N. D., Ramanathan, V., and Gustafsson, Ö.: Source-diagnostic dualisotope composition and optical properties of water-soluble organic carbon and elemental carbon in the South Asian outflow intercepted over the Indian Ocean, J. Geophys. Res.-Atmos., 119, 11743-711759, 2014.

Bucheli, T. D., Blum, F., Desaules, A., and Gustafsson, Ö.: Polycyclic aromatic hydrocarbons, black carbon, and molecular markers in soils of Switzerland, Chemosphere, 56, 1061-1076, 2004.

Cao, J. J., Lee, S. C., Zhang, X. Y., Chow, J. C., An, Z. S., Ho, K. F., Watson, J. G., Fung, K., Wang, Y. Q., and Shen, Z. X.: Characterization of airborne carbonate over a site near Asian dust source regions during spring 2002 and its climatic and environmental significance, J. Geophys. Res.-Atmos., 110, D03203, https://doi.org/10.1029/2004jd005244, 2005.

Cao, J.-J., Xu, B.-Q., He, J.-Q., Liu, X.-Q., Han, Y.-M., Wang, G.H., and Zhu, C.-S.: Concentrations, seasonal variations, and transport of carbonaceous aerosols at a remote Mountainous region in western China, Atmos. Environ., 43, 4444-4452, https://doi.org/10.1016/j.atmosenv.2009.06.023, 2009.

Cao, J., Tie, X., Xu, B., Zhao, Z., Zhu, C., Li, G., and Liu, S.: Measuring and modeling black carbon (BC) contamination in the SE Tibetan Plateau, J. Atmos. Chem., 67, 45-60, https://doi.org/10.1007/s10874-011-9202-5, 2010.

Carrico, C. M., Bergin, M. H., Shrestha, A. B., Dibb, J. E., Gomes, L., and Harris, J. M.: The importance of carbon and mineral dust to seasonal aerosol properties in the Nepal Himalaya, Atmos. Environ., 37, 2811-2824, https://doi.org/10.1016/S13522310(03)00197-3, 2003. 
Cavalli, F., Viana, M., Yttri, K. E., Genberg, J., and Putaud, J. P.: Toward a standardised thermal-optical protocol for measuring atmospheric organic and elemental carbon: the EUSAAR protocol, Atmos. Meas. Tech., 3, 79-89, https://doi.org/10.5194/amt-3-792010, 2010.

Chen, B., Andersson, A., Lee, M., Kirillova, E. N., Xiao, Q., Krusa, M., Shi, M., Hu, K., Lu, Z., Streets, D. G., Du, K., and Gustafsson, O.: Source forensics of black carbon aerosols from China, Environ. Sci. Technol., 47, 9102-9108, https://doi.org/10.1021/es401599r, 2013.

Chen, P., Kang, S., Bai, J., Sillanpää, M., and Li, C.: Yak dung combustion aerosols in the Tibetan Plateau: chemical characteristics and influence on the local atmospheric environment, Atmos. Res., 156, 58-66, https://doi.org/10.1016/j.atmosres.2015.01.001, 2015.

Chow, J. C. and Watson, J. G.: $\mathrm{PM}_{2.5}$ carbonate concentrations at regionally representative interagency monitoring of protected visual environment sites, J. Geophys. Res.-Atmos., 107, 8344, https://doi.org/10.1029/2001jd000574, 2002.

Chow, J. C., Watson, J. G., Pritchett, L. C., Pierson, W. R., Frazier, C. A., and Purcell, R. G.: The dri thermal/optical reflectance carbon analysis system: description, evaluation and applications in US Air quality studies, Atmos. Environ. A.-Gen., 27, 11851201, https://doi.org/10.1016/0960-1686(93)90245-t, 1993.

Chow, J. C., Watson, J. G., Crow, D., Lowenthal, D. H., and Merrifield, T.: Comparison of IMPROVE and NIOSH carbon measurements, Aerosol Sci. Tech., 34, 23-34, https://doi.org/10.1080/027868201300081923, 2001.

Clarke, A. D., Shinozuka, Y., Kapustin, V. N., Howell, S., Huebert, B., Doherty, S., Anderson, T., Covert, D., Anderson, J., Hua, X., Moore, K. G., McNaughton, C., Carmichael, G., and Weber, R.: Size distributions and mixtures of dust and black carbon aerosol in Asian outflow: physiochemistry and optical properties, J. Geophys. Res.-Atmos., 109, D15S09, https://doi.org/10.1029/2003jd004378, 2004.

Cohen, A. S.: Paleolimnology: The History and Evolution of Lake Systems, Oxford University Press, 2003.

Cong, Z., Kang, S., Gao, S., Zhang, Y., Li, Q., and Kawamura, K.: Historical trends of atmospheric black carbon on Tibetan Plateau as reconstructed from a 150 year lake sediment record, Environ. Sci. Technol., 47, 2579-2586, 2013.

Cong, Z., Kang, S., Kawamura, K., Liu, B., Wan, X., Wang, Z., Gao, S., and Fu, P.: Carbonaceous aerosols on the south edge of the Tibetan Plateau: concentrations, seasonality and sources, Atmos. Chem. Phys., 15, 1573-1584, https://doi.org/10.5194/acp15-1573-2015, 2015.

Cornelissen, G., Gustafsson, Ö., Bucheli, T. D., Jonker, M. T., Koelmans, A. A., and van Noort, P. C.: Extensive sorption of organic compounds to black carbon, coal, and kerogen in sediments and soils: mechanisms and consequences for distribution, bioaccumulation, and biodegradation, Environ. Sci. Technol., 39, 68816895, 2005

Decesari, S., Facchini, M. C., Carbone, C., Giulianelli, L., Rinaldi, M., Finessi, E., Fuzzi, S., Marinoni, A., Cristofanelli, P., and Duchi, R.: Chemical composition of $\mathrm{PM}_{10}$ and $\mathrm{PM}_{1}$ at the high-altitude Himalayan station Nepal Climate ObservatoryPyramid (NCO-P) (5079 ma.s.1.), Atmos. Chem. Phys., 10, 4583-4596, https://doi.org/10.5194/acp-10-4583-2010, 2010.
Doberschütz, S., Frenzel, P., Haberzettl, T., Kasper, T., Wang, J., Zhu, L., Daut, G., Schwalb, A., and Mäusbacher, R.: Monsoonal forcing of Holocene paleoenvironmental change on the central Tibetan Plateau inferred using a sediment record from Lake Nam Co (Xizang, China), J. Paleolimnol., 51, 253-266, https://doi.org/10.1007/s10933-013-9702-1, 2014.

Fang, Y., Chen, Y., Tian, C., Lin, T., Hu, L., Huang, G., Tang, J., Li, J., and Zhang, G.: Flux and budget of BC in the continental shelf seas adjacent to Chinese high BC emission source regions, Global Biogeochem. Cy., 29, 957-972, https://doi.org/10.1002/2014gb004985, 2015.

Gustafsson, Ö. and Gschwend, P. M.: The flux of black carbon to surface sediments on the New England continental shelf, Geochim. Cosmochim. Ac., 62, 465-472, 1998.

Hammes, K., Schmidt, M. W. I., Smernik, R. J., Currie, L. A., Ball, W. P., Nguyen, T. H., Louchouarn, P., Houel, S., Gustafsson, O., Elmquist, M., Cornelissen, G., Skjemstad, J. O., Masiello, C. A., Song, J., Peng, P. a., Mitra, S., Dunn, J. C., Hatcher, P. G., Hockaday, W. C., Smith, D. M., Hartkopf-Froeder, C., Boehmer, A., Lueer, B., Huebert, B. J., Amelung, W., Brodowski, S., Huang, L., Zhang, W., Gschwend, P. M., Flores-Cervantes, D. X., largeau, C., Rouzaud, J.-N., Rumpel, C., Guggenberger, G., Kaiser, K., Rodionov, A., Gonzalez-Vila, F. J., GonzalezPerez, J. A., de la Rosa, J. M., Manning, D. A. C., LopezCapel, E., and Ding, L.: Comparison of quantification methods to measure fire-derived (black/elemental) carbon in soils and sediments using reference materials from soil, water, sediment and the atmosphere, Global Biogeochem. Cy., 21, GB3016, https://doi.org/10.1029/2006gb002914, 2007.

Han, Y. M., Cao, J. J., Yan, B. Z., Kenna, T. C., Jin, Z. D., Cheng, Y., Chow, J. C., and An, Z. S.: Comparison of elemental carbon in lake sediments measured by three different methods and 150 year pollution history in eastern China, Environ. Sci. Technol., 45, 5287-5293, 2011.

Han, Y., Wei, C., Bandowe, B., Wilcke, W., Cao, J., Xu, B., Gao, S., Tie, X., Li, G., and Jin, Z.: Elemental carbon and polycyclic aromatic compounds in a 150 year sediment core from Lake Qinghai, Tibetan Plateau, China: influence of regional and local sources and transport pathways, Environ. Sci. Technol., 49, 4176-4183, 2015.

Han, Y. M., Wei, C., Huang, R. J., Bandowe, B. A. M., Ho, S. S. H., Cao, J. J., Jin, Z. D., Xu, B. Q., Gao, S. P., Tie, X. X., An, Z. S., and Wilcke, W.: Reconstruction of atmospheric soot history in inland regions from lake sediments over the past 150 years, Sci. Rep.-UK, 6, 19151, https://doi.org/10.1038/srep19151, 2016.

Ho, K. F., Zhang, R. J., Lee, S. C., Ho, S. S. H., Liu, S. X., Fung, K., Cao, J. J., Shen, Z. X., and Xu, H. M.: Characteristics of carbonate carbon in $\mathrm{PM}_{2.5}$ in a typical semi-arid area of Northeastern China, Atmos. Environ., 45, 1268-1274, https://doi.org/10.1016/j.atmosenv.2010.12.007, 2011.

Jankowski, N., Schmidl, C., Marr, I. L., Bauer, H., and Puxbaum, H.: Comparison of methods for the quantification of carbonate carbon in atmospheric $\mathrm{PM}_{10}$ aerosol samples, Atmos. Environ., 42, 8055-8064, https://doi.org/10.1016/j.atmosenv.2008.06.012, 2008.

Ji, Z., Kang, S., Cong, Z., Zhang, Q., and Yao, T.: Simulation of carbonaceous aerosols over the Third Pole and adjacent regions: distribution, transportation, deposition, and climatic effects, Clim. 
Dynam., 45, 2831-2846, https://doi.org/10.1007/s00382-0152509-1, 2015.

Jurado, E., Dachs, J., Duarte, C. M., and Simo, R.: Atmospheric deposition of organic and black carbon to the global oceans, Atmos. Environ., 42, 7931-7939, 2008.

Kang, S., Xu, Y., You, Q., Flügel, W.-A., Pepin, N., and Yao, T.: Review of climate and cryospheric change in the Tibetan Plateau, Environ. Res. Lett., 5, 015101, https://doi.org/10.1088/17489326/5/1/015101, 2010.

Karanasiou, A., Diapouli, E., Cavalli, F., Eleftheriadis, K., Viana, M., Alastuey, A., Querol, X., and Reche, C.: On the quantification of atmospheric carbonate carbon by thermal/optical analysis protocols, Atmos. Meas. Tech., 4, 2409 2419, https://doi.org/10.5194/amt-4-2409-2011, 2011.

Karanasiou, A., Minguillón, M. C., Viana, M., Alastuey, A., Putaud, J. P., Maenhaut, W., Panteliadis, P., Močnik, G., Favez, O., and Kuhlbusch, T. A. J.: Thermal-optical analysis for the measurement of elemental carbon (EC) and organic carbon (OC) in ambient air a literature review, Atmos. Meas. Tech. Discuss., 8, 9649-9712, https://doi.org/10.5194/amtd-8-9649-2015, 2015.

Kaspari, S. D., Schwikowski, M., Gysel, M., Flanner, M. G., Kang, S., Hou, S., and Mayewski, P. A.: Recent increase in black carbon concentrations from a Mt. Everest ice core spanning 1860-2000 AD, Geophys. Res. Lett., 38, L04703, https://doi.org/10.1029/2010gl046096, 2011.

Koch, D., Schulz, M., Kinne, S., McNaughton, C., Spackman, J. R., Balkanski, Y., Bauer, S., Berntsen, T., Bond, T. C., Boucher, O., Chin, M., Clarke, A., De Luca, N., Dentener, F., Diehl, T., Dubovik, O., Easter, R., Fahey, D. W., Feichter, J., Fillmore, D., Freitag, S., Ghan, S., Ginoux, P., Gong, S., Horowitz, L., Iversen, T., Kirkevag, A., Klimont, Z., Kondo, Y., Krol, M., Liu, X., Miller, R., Montanaro, V., Moteki, N., Myhre, G., Penner, J. E., Perlwitz, J., Pitari, G., Reddy, S., Sahu, L., Sakamoto, H., Schuster, G., Schwarz, J. P., Seland, O., Stier, P., Takegawa, N., Takemura, T., Textor, C., van Aardenne, J. A., and Zhao, Y.: Evaluation of black carbon estimations in global aerosol models, Atmos. Chem. Phys., 9, 9001-9026, https://doi.org/10.5194/acp-9-9001-2009, 2009.

Lau, W. K. M., Kim, M.-K., Kim, K.-M., and Lee, W.-S.: Enhanced surface warming and accelerated snow melt in the Himalayas and Tibetan Plateau induced by absorbing aerosols, Environ. Res. Lett., 5, 025204, https://doi.org/10.1088/1748-9326/5/2/025204, 2010.

Li, C., Kang, S., Wang, X., Ajmone-Marsan, F., and Zhang, Q.: Heavy metals and rare earth elements (REEs) in soil from the Nam Co Basin, Tibetan Plateau, Environ. Geol., 53, 1433-1440, https://doi.org/10.1007/s00254-007-0752-4, 2008.

Li, C., Kang, S., Zhang, Q., and Wang, F.: Rare earth elements in the surface sediments of the Yarlung Tsangbo (Upper Brahmaputra River) sediments, southern Tibetan Plateau, Quatern. Int., 208, 151-157, 2009.

Li, Q., Kang, S., Zhang, Q., Huang, J., guo, J., Wang, K., and Wang, J.: A 150 year climate change history reconstructed by lake sediment of Nam Co, Tibetan Plateau (in Chinese), Acta Sedimentologica Sinica, 32, 669-676, 2014.

Li, C., Bosch, C., Kang, S., Andersson, A., Chen, P., Zhang, Q., Cong, Z., Chen, B., Qin, D., and Gustafsson, Ö.: Sources of black carbon to the Himalayan-Tibetan Plateau glaciers, Nat. Commun., 7, 12574, https://doi.org/10.1038/ncomms12574, 2016a.

Li, C., Chen, P., Kang, S., Yan, F., Hu, Z., Qu, B., and Sillanpää, M.: Concentrations and light absorption characteristics of carbonaceous aerosol in $\mathrm{PM}_{2.5}$ and $\mathrm{PM}_{10}$ of Lhasa city, the Tibetan Plateau, Atmos. Environ., 127, 340-346, https://doi.org/10.1016/j.atmosenv.2015.12.059, $2016 \mathrm{~b}$.

Li, C., Chen, P., Kang, S., Yan, F., Li, X., Qu, B., and Sillanpää, M.: Carbonaceous matter deposition in the high glacial regions of the Tibetan Plateau, Atmos. Environ., 141, 203-208, https://doi.org/10.1016/j.atmosenv.2016.06.064, 2016c.

Li, C., Yan, F., Kang, S., Chen, P., Hu, Z., Gao, S., Qu, B., and Sillanpää, M.: Light absorption characteristics of carbonaceous aerosols in two remote stations of the southern fringe of the Tibetan Plateau, China, Atmos. Environ., 143, 79-85, https://doi.org/10.1016/j.atmosenv.2016.08.042, 2016d.

Li, X., Kang, S., He, X., Qu, B., Tripathee, L., Jing, Z., Paudyal, R., Li, Y., Zhang, Y., Yan, F., Li, G., and Li, C.: Light-absorbing impurities accelerate glacier melt in the Central Tibetan Plateau, Sci. Total Environ., 587, 482-490, https://doi.org/10.1016/j.scitotenv.2017.02.169, 2017.

Lim, S., Faïn, X., Zanatta, M., Cozic, J., Jaffrezo, J. L., Ginot, P., and Laj, P.: Refractory black carbon mass concentrations in snow and ice: method evaluation and inter-comparison with elemental carbon measurement, Atmos. Meas. Tech., 7, 3307-3324, https://doi.org/10.5194/amt-7-3307-2014, 2014.

Liu, B., Cong, Z., Wang, Y., Xin, J., Wan, X., Pan, Y., Liu, Z., Wang, Y., Zhang, G., Wang, Z., Wang, Y., and Kang, S.: Background aerosol over the Himalayas and Tibetan Plateau: observed characteristics of aerosol mass loading, Atmos. Chem. Phys., 17, 449-463, https://doi.org/10.5194/acp-17-449-2017, 2017.

Liu, Y.-H., Dong, G.-R., Li, S., and Dong, Y.-X.: Status, causes and combating suggestions of sandy desertification in qinghai-tibet plateau, Chinese Geogr. Sci., 15, 289-296, https://doi.org/10.1007/s11769-005-0015-9, 2005.

Maenhaut, W., Schwarz, J., Cafmeyer, J., and Chi, X.: Aerosol chemical mass closure during the EUROTRAC-2 AEROSOL Intercomparison 2000, Nucl. Instrum. Meth. B, 189, 233-237, https://doi.org/10.1016/S0168-583X(01)01048-5, 2002.

Marinoni, A., Cristofanelli, P., Laj, P., Duchi, R., Calzolari, F., Decesari, S., Sellegri, K., Vuillermoz, E., Verza, G. P., Villani, P., and Bonasoni, P.: Aerosol mass and black carbon concentrations, a two year record at NCO-P (5079 m, Southern Himalayas), Atmos. Chem. Phys., 10, 8551-8562, https://doi.org/10.5194/acp10-8551-2010, 2010.

Ming, J., Zhang, D., Kang, S., and Tian, W.: Aerosol and fresh snow chemistry in the East Rongbuk Glacier on the northern slope of Mt. Qomolangma (Everest), J. Geophys. Res., 112, D15307, https://doi.org/10.1029/2007JD008618, 2007.

Ming, J., Cachier, H., Xiao, C., Qin, D., Kang, S., Hou, S., and $\mathrm{Xu}$, J.: Black carbon record based on a shallow Himalayan ice core and its climatic implications, Atmos. Chem. Phys., 8, 13431352, https://doi.org/10.5194/acp-8-1343-2008, 2008.

Ming, J., Xiao, C., Cachier, H., Qin, D., Qin, X., Li, Z., and Pu, J.: Black carbon (BC) in the snow of glaciers in west China and its potential effects on albedos, Atmos. Res., 92, 114-123, 2009.

Ming, J., Xiao, C., Sun, J., Kang, S., and Bonasoni, P.: Carbonaceous particles in the atmosphere and precipitation of the 
Nam Co region, Central Tibet, J. Environ. Sci., 22, 1748-1756, 2010.

Ming, J., Xiao, C., Du, Z., and Yang, X.: An overview of black carbon deposition in High Asia glaciers and its impacts on radiation balance, Adv. Water Resour., 55, 80-87, https://doi.org/10.1016/j.advwatres.2012.05.015, 2013.

Perrone, M. R., Piazzalunga, A., Prato, M., and Carofalo, I.: Composition of fine and coarse particles in a coastal site of the central Mediterranean: carbonaceous species contributions, Atmos. Environ., 45, 7470-7477, 2011.

Pio, C. A., Legrand, M., Oliveira, T., Afonso, J., Santos, C., Caseiro, A., Fialho, P., Barata, F., Puxbaum, H., SanchezOchoa, A., Kasper-Giebl, A., Gelencser, A., Preunkert, S., and Schock, M.: Climatology of aerosol composition (organic versus inorganic) at nonurban sites on a west-east transect across Europe, J. Geophys. Res.-Atmos., 112, D23S02, https://doi.org/10.1029/2006jd008038, 2007.

Qu, B., Ming, J., Kang, S. C., Zhang, G. S., Li, Y. W., Li, C. D., Zhao, S. Y., Ji, Z. M., and Cao, J. J.: The decreasing albedo of the Zhadang glacier on western Nyainqentanglha and the role of light-absorbing impurities, Atmos. Chem. Phys., 14, 1111711128, https://doi.org/10.5194/acp-14-11117-2014, 2014.

Ram, K., Sarin, M. M., and Tripathi, S. N.: A 1 year record of carbonaceous aerosols from an urban site in the Indo-Gangetic Plain: characterization, sources, and temporal variability, J. Geophys. Res., 115, 9-12, 2010.

Ramanathan, V. and Carmichael, G.: Global and regional climate changes due to black carbon, Nat. Geosci., 1, 221-227, 2008.

Reisinger, P., Wonaschütz, A., Hitzenberger, R., Petzold, A., Bauer, H., Jankowski, N., Puxbaum, H., Chi, X., and Maenhaut, W.: Intercomparison of measurement techniques for black or elemental carbon under urban background conditions in wintertime: influence of biomass combustion, Environ. Sci. Technol., 42, 884-889, https://doi.org/10.1021/es0715041, 2008.

Ruppel, M. M., Isaksson, E., Ström, J., Beaudon, E., Svensson, J., Pedersen, C. A., and Korhola, A.: Increase in elemental carbon values between 1970 and 2004 observed in a 300 year ice core from Holtedahlfonna (Svalbard), Atmos. Chem. Phys., 14, 11447-11460, https://doi.org/10.5194/acp-14-11447-2014, 2014.

Sillanpää, M., Frey, A., Hillamo, R., Pennanen, A. S., and Salonen, R. O.: Organic, elemental and inorganic carbon in particulate matter of six urban environments in Europe, Atmos. Chem. Phys., 5, 2869-2879, https://doi.org/10.5194/acp-5-2869-2005, 2005.

Tang, Y., Han, G. L., and Xu, Z. F.: Atmospheric black carbon deposit in Beijing and Zhangbei, China, in: Geochemistry of the Earth's Surface Ges-10, edited by: Gaillardet, J., Procedia Earth and Planetary Science, 383-387, 2014.

Viidanoja, J., Sillanpaa, M., Laakia, J., Kerminen, V. M., Hillamo, R., Aarnio, P., and Koskentalo, T.: Organic and black carbon in $\mathrm{PM}_{2.5}$ and $\mathrm{PM}_{10}$ : 1 year of data from an urban site in Helsinki, Finland, Atmos. Environ., 36, 3183-3193, https://doi.org/10.1016/s1352-2310(02)00205-4, 2002.

Wan, D. J., Jin, Z. D., and Wang, Y. X.: Geochemistry of eolian dust and its elemental contribution to Lake Qinghai sediment, Appl. Geochem., 27, 1546-1555, https://doi.org/10.1016/j.apgeochem.2012.03.009, 2012.
Wan, X., Kang, S., Wang, Y., Xin, J., Liu, B., Guo, Y., Wen, T., Zhang, G., and Cong, Z.: Size distribution of carbonaceous aerosols at a high-altitude site on the central Tibetan Plateau (Nam Co Station, 4730 ma.s.1.), Atmos. Res., 153, 155-164, https://doi.org/10.1016/j.atmosres.2014.08.008, 2015.

Wang, S., Wang, J., Zhou, Z., and Shang, K.: Regional characteristics of three kinds of dust storm events in China, Atmos. Environ., 39, 509-520, https://doi.org/10.1016/j.atmosenv.2004.09.033, 2005.

Wang, J., Zhu, L., Wang, Y., Gao, S., and Daut, G.: Spatial variability of recent sedimentation rate and variations in the past 60 years in Nam Co, Tibetan Palteau, China (in Chinese), Quaternary Sci. Rev., 31, 535-543, 2011.

Watson, J. G., Chow, J. C., and Chen, L. W. A.: Summary of organic and elemental carbon/black carbon analysis methods and intercomparisons, Aerosol Air Qual. Res., 5, 65-102, 2005.

Wu, Y., Zhu, L., Ye, Q., and Wang, L.: The response of lake-glacier area change to climate variations in Namco Basin, Central Tibetan Plateau, during the last three decades (in Chinese), Acta Geographica Sinica, 62, 301-311, 2007.

Xu, B., Cao, J., Hansen, J., Yao, T., Joswia, D. R., Wang, N., Wu, G., Wang, M., Zhao, H., and Yang, W.: Black soot and the survival of Tibetan glaciers, P. Natl. Acad. Sci. USA, 106, 22114-22118, 2009.

Xu, Y., Ramanathan, V., and Washington, W. M.: Observed high-altitude warming and snow cover retreat over Tibet and the Himalayas enhanced by black carbon aerosols, Atmos. Chem. Phys., 16, 1303-1315, https://doi.org/10.5194/acp-161303-2016, 2016.

Yan, C., Zheng, M., Sullivan, A. P., Bosch, C., Desyaterik, Y., Andersson, A., Li, X., Guo, X., Zhou, T., Gustafsson, Ö., and Collett Jr, J. L.: Chemical characteristics and lightabsorbing property of water-soluble organic carbon in Beijing: biomass burning contributions, Atmos. Environ., 121, 4-12, https://doi.org/10.1016/j.atmosenv.2015.05.005, 2015.

Yang, H.: Lake sediments may not faithfully record decline of atmospheric pollutant deposition, Environ. Sci. Technol., 49, $12607-$ 12608, https://doi.org/10.1021/acs.est.5b04386, 2015.

You, Q., Kang, S., Pepin, N., Fluegel, W.-A., Yan, Y., Behrawan, H., and Huang, J.: Relationship between temperature trend magnitude, elevation and mean temperature in the Tibetan Plateau from homogenized surface stations and reanalysis data, Glob. Planet. Change, 71, 124-133, https://doi.org/10.1016/j.gloplacha.2010.01.020, 2010.

Zhang, G., Yao, T., Piao, S., Bolch, T., Xie, H., Chen, D., Gao, Y., O’Reilly, C. M., Shum, C. K., Yang, K., Yi, S., Lei, Y., Wang, W., He, Y., Shang, K., Yang, X., and Zhang, H.: Extensive and drastically different alpine lake changes on Asia's high plateaus during the past four decades, Geophys. Res. Lett., 44, 252-260, https://doi.org/10.1002/2016gl072033, 2017a.

Zhang, R., Wang, H., Qian, Y., Rasch, P. J., Easter, R. C., Ma, P. L., Singh, B., Huang, J., and Fu, Q.: Quantifying sources, transport, deposition, and radiative forcing of black carbon over the Himalayas and Tibetan Plateau, Atmos. Chem. Phys., 15, 62056223, https://doi.org/10.5194/acp-15-6205-2015, 2015.

Zhang, Y., Kang, S., Cong, Z., Schmale, J., Sprenger, M., Li, C., Yang, W., Gao, T., Sillanpää, M., and Li, X.: Light-absorbing impurities enhance glacier albedo reduction in the southeastern Tibetan Plateau, J. Geophys. Res.-Atmos., 122, 6915-6933, 2017 b. 
Zhao, S., Ming, J., Sun, J., and Xiao, C.: Observation of carbonaceous aerosols during 2006-2009 in Nyainqntanglha Mountains and the implications for glaciers, Environ. Sci. Pollut. R., 20, 5827-5838, https://doi.org/10.1007/s11356-013-1548-6, 2013a.

Zhao, Z., Cao, J., Shen, Z., Xu, B., Zhu, C., Chen, L. W. A., Su, X., Liu, S., Han, Y., Wang, G., and Ho, K.: Aerosol particles at a high-altitude site on the Southeast Tibetan Plateau, China: implications for pollution transport from South Asia, J. Geophys. Res.-Atmos., 118, 11360-11375, https://doi.org/10.1002/jgrd.50599, 2013b.
Zhao, Z. Z., Cao, J. J., Shen, Z. X., Huang, R. J., Hu, T. F., Wang, P., Zhang, T., and Liu, S. X.: Chemical composition of $\mathrm{PM}_{2.5}$ at a high-altitude regional background site over Northeast of Tibet Plateau, Atmos. Pollut. Res., 6, 815-823, https://doi.org/10.5094/apr.2015.090, 2015.

Zhu, L., Xie, M., and Wu, Y.: Quantitative analysis of lake area variations and the influence factors from 1971 to 2004 in the Nam Co basin of the Tibetan Plateau, Chinese Sci. Bull., 55, 1294-1303, 2010 . 